\title{
THE EFFECT OF MANUFACTURING VALUE ADDED ON ECONOMIC GROWTH: EMPRICAL EVIDENCE FROM EUROPE
}

DOI: 10.17261/Pressacademia.2019.1044

JBEF- V.8-ISS.2-2019(6)-p.133-146

Mohammad Karami ${ }^{1}$, Naser Elahinia ${ }^{2}$, Shekoufeh Karami ${ }^{3}$

${ }^{1}$ Eastern Mediterranean University, Department of Business Administration, Cyprus. Mohammad.karami6990@gmail.com ORCID ID: 0000-0003-1903-828X

2 Eastern Mediterranean University, Department of Business Administration, Cyprus. Naserelahinia@gmail.com ORCID ID: 0000-0002-7280-8872

${ }^{3}$ Amin Institute of Higher Education, Department of Business Administration, Iran. Shekoufehkarami86@gmail.com ORCID ID: 0000-0003-1006-3032

Date Received: April 30, 2019

Date Accepted: June 5, 2019

To cite this document

Karami, M., Elahinia, N., Karami, Sh (2019). The effect of manufacturing value added on economic growth: empirical evidence from Europe. Journal of Business Economics and Finance (JBEF), V.8(2), p.133-146, DOI: 10.17261/Pressacademia.2019.1044

Permemant link to this document: $\mathrm{http}: / /$ doi.org/10.17261/Pressacademia.2019.1044

Copyright: Published by PressAcademia and limited licenced re-use rights only.

\section{ABSTRACT}

Purpose- The purpose of this study is to examine the impact of manufacturing on economic growth in European economies during the period of deindustrialization. Moreover, the associations between capital, labor force, and technology with economic growth have been investigated. Methodology- Econometric tests are performed based on a panel data for twenty-five of most competitive European economies for the period 1995 - 2016. To quantify the relationship between explanatory variables and economic growth, an eclectic model consists of both the Kaldor's first law of growth and the neoclassical growth model was estimated.

Findings- The result of this study revealed that the economic growth has a significantly positive association with manufacturing, labor force, and technology. The unexpected interesting result is that the association between economic growth and investment is significantly negative.

Conclusion- Research stated that policy makers should invest in those policies that can enhance the growth of the manufacturing sector by increases of manufacturing productivity and increases in the manufacturing employment share to create job opportunities in this sector in order to have a sustainable, healthy and competitive economic development in future.

Keywords: Kaldorian Approach, deindustrialization, economic growth, manufacturing value added, European Economy. JEL Codes: L60, O47, 014, 052

\section{INTRODUCTION}

Historically, manufacturing has played essential role in economic development in any nation (Naudé, Szirmai, and Haraguchi, 2016). National economies that could quickly harness its power, had realized abundant wealth, productivity, and significant development in their countries through manufacturing (Oyati, 2010). The stories of the advanced nations and those of emerging economies like India, China, North Korea, Singapore, and Malaysia showed a positive connection between national economic growth and the growth of manufacturing sector (Banjoko, Iwuji, and Bagshaw, 2012).

According to European Central Bank (2015), with nearly 340 million people, the euro area is one of the biggest economies in terms of population. While in terms of its share of global GDP, it is the third-largest economy, coming after the United States of 
America and the People's Republic of China (Table 1). The manufacturing sector engaged 29.9 million persons in gainful employment in the year 2014, generating $€ 1.710$ billion of added value. Using these measures, manufacturing was NACE's ${ }^{1}$ second-biggest section within Europe's non-financial business economy in terms of what it contributes in job creation (22.1\%) and the major contributor to non-financial business economy value added, which accounts for more than one-quarter of the total (26.0\%) (Eurostat, 2018).

\section{Table 1: Share of World GDP of the Euro Area in 2016}

\begin{tabular}{|c|c|c|c|c|c|}
\hline & Unit & Euro Area & U.S. & Japan & China \\
\hline Population & Millions & 340.2 & 323.4 & 127.0 & 1382.7 \\
\hline GDP (share of world GDP in PPP) & $\%$ & 11.7 & 15.5 & 4.4 & 17.7 \\
\hline
\end{tabular}

Source: European Central Bank, 2015

In spite of all well-known advantages of manufacturing sector, for a number of years now, Europe and some other parts of the world have moved into a deindustrialization process (Dhéret and Morosi, 2014). Deindustrialization in advanced economies, which is given away by the incessant decline in manufacturing sector's contribution to job creation and the GDP as well as the increase in contribution of service sector to the GDP, has not been generally viewed as a negative occurrence, but rather as an expected result in the process of economic development (Rowthorn and Ramaswamy, 1997). This process can somewhat be credited to shifts in policies and drastic economic reforms than to the maturity of economic structures (Arestis, Sawyer, and Palma, 2005).

A recent report of the European Commission (2014) has placed emphasis on the significance of the real economy, and robust industry as a driver of employment and economic development. In its policy vision, the targeted input of industry to the growth of GDP by 2020 has been raised up to $20 \%$. For Europe's competitiveness and economic recovery, a robust industrial base is seen as fundamental.

Investigation of the long-standing correlation that exists between economic growth and manufacturing output for competitive European economies in the period of the phenomenon of deindustrialization has been rarely investigated in the literature. Therefore, based of Europe's future policies it is essential to study the role of manufacturing in economic growth for the future in the Europe's economic region.

The purpose of this research is to investigate the role that manufacturing sector has played in driving the growth in twenty-five most competitive European economies for the period between 1995-2016 by conducting a descriptive analysis, OLS regression, Pearson correlation, fixed and random effects model. To quantify the correlation between economic growth and manufacturing output, an eclectic model consisting of both the Kaldor's first law of growth and neoclassical growth model was estimated.

Aside this introduction, the second chapter aims to investigate the essence of the relationship between the manufacturing sector and economic development as well as to also discuss theories which have been used in previous related studies. The third chapter is research methodology which explains data collection, a model of the study and all estimation methods which have been conducted. Section 4 shows the findings of the study by outlining the results while section 5 discusses the results from the models, the implications, the contribution, as well as the limitations of this study. At the end, section 6 contains the conclusion of the study.

\section{LITERATURE REVIEW}

Based on theoretic and various empirical researches in the literature, manufacturing output, level of technology, investment, and labor force have played an essential role in any nation as the main important factors to influence the real gross domestic in long run. Kaldor's first law growth theory (Kaldor, 1966) and neoclassical growth theory (Solow, 1956) separately show the importance of the mentioned factors in long-run economic growth.

1 Statistical Classification of Economic Activities in the European Community 


\subsection{Theoretical Literature}

\subsubsection{Kaldor Growth Theory}

Nicholas Kaldor's paper was published in 1966, on the reasons for the United Kingdom's poor economic progress in that particular period .Kaldor carried out a structural, empirical and comparative study, concentrating on the part the manufacturing sector plays roles in economic development (Kaldor, 1966). This 1966 paper of Kaldor came to be an important reference as it contains the basis of the hypothetical formulation which was later acknowledged as Kaldor's growth laws. Kaldor's growth laws acclaim vital significance to the manufacturing industry for economic growth. He further posited that the growth passage of advanced nations in the post-war era (over the period 1952-54 to 1963-64) displayed the association between industrial development and the entire economic performance of a nation. This statement formed the basis for the first law of Kaldor which says that a close association exists between increasing in manufacturing output and increasing in gross domestic product (GDP). This first law can be expressed briefly as the manufacturing industry is the engine of economic growth. The linear specification of the first law of Kaldor is as follow:

$$
\text { "gGDP }=\mathbf{a}_{0}+\mathbf{a}_{1} \text { gMAN" }
$$

Where:

gGDP: The growth of total output.

gMAN: The growth of the manufacturing output.

It is significant to be aware that the association these two variables have is not only as a result of the manufacturing output but represents a huge constituent of total output. The total rate at which the economy grows is connected to the excess rate of growth of the manufacturing output over the rate of growth of the non- manufacturing output. All this implies that good growth is typically found in circumstances where manufacturing industry's share in the GDP is increasing (Libanio and Moro, 2006). Kaldor's work turned out to be an essential turning point in the economic growth literature.

\subsubsection{Neoclassical Growth Theory}

The theory of economic growth has developed with an American economist Robert Solow (1956). Some are of the opinion that the theory of economic growth, developed in the middle of the twentieth century, recognizing the set of technological advancement as a significant element of the economic development of nations (Solow, 1956). He paid attention to the course of capital formation as well as presumed that production was a function of labor, technology, and capital. He observed that if the only drawback to economic development were capital, then producers will replace capital with labor. At that juncture, his input focused on the result that sustainable growth is influenced by changes in technology and not investment or savings. Saving only has an impact on growth temporarily, or growth on its way to sustainability, for the reason that the economy will trip into diminishing returns as the ratio of capital per worker rises.

The structure for the development of the total factor productivity (TFP) concept is provided by Solow's model where labor augmenting, technological change and the increase of capital per worker explain the long-term growth of the economy per worker. Of late, conditional convergence, a model which is a derivative of these models is widely in use. This empirical property is founded on the supposition of capital's diminishing return as a result economy with reasonably low capital per worker rates have a tendency to develop quicker owing to higher rates of return (Dragutinović, Filipović, and Cvetanović, 2005). The production function is the logical beginning point of Solow model. The linear specification of the Solow model is as follow:

$$
\mathbf{Y}=\mathbf{T F}(\mathbf{K}, \mathbf{L})
$$

Where:

K: Physical capital

T: Technology

$\mathrm{L}$ : Amount of worker

Y: Production (GDP) 
Neoclassical growth model reveals that, at the point of long-term steady equilibrium, technological changes effect on economic development.

\subsection{Empirical Literature}

\subsubsection{Manufacturing and Economic Growth}

It is well supported in development and growth literature that a strong causal relationship exists between the manufacturing growth and its GDP growth in any nation (Pacheco-López and Thirlwall, 2013). Szirmai and Verspagen (2015) analyzed the correlation between the manufacturing value added (MVA) and GDP for 92 countries in the period of 1950-1970, 1970-1990 and 1990-2005 using random effects, fixed effects and Hausman tests. They discovered that the manufacturing sector performances the role of a growth engine for low and a few middle-income economies if there is an adequate level of manpower. These kinds of growth engine characteristics are not applicable to the service sector. Szirmai and Verspagen (2015) re-examined the part that manufacturing plays as a growth driver in industrialized and emerging economies during 1950-2005 period using manufacturing value added (MVA) as indicator for manufacturing output. The examination reported that there is a reasonable positive effect of MVA on economic development.

Real growth rates of GDP were regressed on manufacturing growth rates by Fagerberg and Verspagen (1999). The regression results show that the manufacturing was an engine of economic development in East Asia's and Latin America's developing countries; nonetheless, there is no significant result of manufacturing in the developed countries. Subsequently, Fagerberg and Verspagen (2002) analyzed the effect of manufacturing and services on economic development in these three periods: 19661972, 1973-1983 and 1984-1995 for 76 countries. They discovered that before 1973 manufacturing had greater positive impacts than after 1973.

In case of on middle-income economies, Su and Yao (2017) by using analysis long-run Granger causality tests, cross-sectional regression and panel regression showed that manufacturing sector growth drives services sector growth. These findings have led the authors to conclude that manufacturing is indeed the growth engine of economies and, hence, that premature deindustrialization has negative effects on economic growth.

Chakravarty and Mitra (2009) also Kathuria and Natarajan (2013) tested the engine of development hypothesis in India, a place where the service sector plays a significant role in the economic growth. In a previous study by Chakravarty and Mitra (2009), covering the 1973 to 2004 period, it was found that manufacturing, services, and constructions have been the drivers of growth. Kathuria, Raj, and Sen (2013) examined the same hypothesis in India for 15 states in 1994-1995 to the 2005-2006 periods and came to the conclusion that manufacturing had strong effect in economic growth in India, in spite of its diminishing GDP share.

Szirmai (2012) reiterated no uncertainty about manufacturing being a significant growth driver in most emerging economies. He concluded that out of the 90 countries sample during the 1950-2005 periods, the statistical findings reveals that manufacturing's prominent role is uncertain and therefore questions if manufacturing will remain growth engine of economies.

Herman (2016) using statistical analysis of the Romanian economic data affirmed that the process of deindustrialization is demonstrated by the decrease in the share of manufacturing in job creation and GDP. Since the year 2000, the force of the process of deindustrialization decreased allowing manufacturing to continue as the backbone of the Romanian economy.

\subsubsection{Investment and Economic Growth}

An investment is an item or asset which is bought due to the desire to appreciate or to generate profit in the future. From the economic view, investment is the action of purchasing some goods which are not consumed today, but they would be utilized in the future to generate wealth instead. Investment in equipment and machinery is strongly associated with growth, using the Penn World Table and the United Nations Comparison Project between 1960 and 1985 (Long and Summers, 1991).

Dritsakis, Varelas, and Adamopoulos (2006) empirically investigated the causality among economic growth, gross capital formation, exports, and foreign direct investments for Greece over 1960-2002 period using a multivariate autoregressive VAR model. The results of co-integration test submitted that only one co-integrated vector exists between the examined variables, 
whereas Granger causal relationship tests revealed a unidirectional causality between gross fixed capital formation and export, the unidirectional causal relationship also exists between economic growth and foreign direct investments.

Blomstrom, Lipsey, and Zejan (1993) showed that an increase in the formation rate of fixed capital would cause a rapid growth in per capita GDP via using the simple causality by working on 100 countries. Also, Kolmakov, Polyakova, and Shalaev (2015) showed that Venture Capital Investment (VCI) significantly affects GDP in Russia and US on a yearly basis during 1998-2011. Ibrahim and Okunade (2015) denoted that the data of the years between 1980 and 2013 of Nigeria conveys a significantly strong influence of domestic and foreign investment on economic development in a long and short run. Furthermore, Nasreen, Anwar, and Waqar (2015) showed that both human and physical capital investment has a positive impact on the growth of the economy via using data from 94 countries during 1985-2009.

\subsubsection{Labor Force and Economic Growth}

For many years, the association between economic development and job creation has been one of the broadly researched topics in economics. Seyfried (2011) examined the correlation between employment and economic growth from 1990 to 2003 in the biggest ten states. To estimate the employment strength of economic development as well as the timing of the association between economic development and employment, models were developed. Employment intensity was calculated to vary from $0.31-0.61$ in particular states against the 0.47 estimate for the whole US. Likewise, results indicated that although economic development does have some direct effect on employment, its impacts remained for a number of quarters in most states examined.

Evangelista, Pianta, and Perani (1996) reported an indication that the reformation of key sectors of the economy reduces the relationship between economic growth and employment. Of all the G7 nations they examined (which excluded Canada), a significant and positive relationship exists between employment growth in value added was only reported for the US and Germany.

Boltho and Glyn (1995) investigated the correlation between economic growth and employment in a set of OECD economies. The results revealed that employment's intensity was 0.5 and 0.63 in the $1973-1979$ and 1982-1993 periods respectively while it was 0.49 in 1075-1982 periods. In this study the changes of elasticity clearly shows that the relationship between employment and economic growth are affected by economic situation of each country.

\subsubsection{Technology and Economic Growth}

For almost five decades, the association between economic growth and technology has been reported extensively in formal models. Gani (2009) examined the association between per capita economic growth in nations with advanced levels of technological success and high-tech exports. The panel regression results for 45 countries in the period of 1996-2004 shown that high-tech exports have a positive significant impact on the development of the technical leader category of nations and a statistically insignificant but positive impact on the potential leader category of nations.

Falk (2009) investigated the effect of the high-tech export on economic development. He calculated a growth model on panel data for 22 OECD nations in the period of 1980-2004. Employing the system GMM panel estimator that adjusts in case of simultaneity, he discovered that the share of high-tech exports and the intensity of RandD for business are positively and significantly linked to the GDP.

Bujari and Martínez (2016) analyzed the effect of technical improvement on the growth of the economy of twelve Latin American nations in the 1996-2008 periods. For the examination, he came up with a dynamic panel data model and estimated with Generalized Method of Moments (GMM) system. Their examination revealed that in the Latin American region, technological innovation processes have a positive impact on economic development.

\subsection{HYPOTHESIS DEVELOPEMENT}

Based on the above literature reviews it has been determined that manufacturing, investment, labor force, and technology influence GDP in the long-term. Previous literature reviews also demonstrated that because of the deindustrialization 
phenomena, the impact of these factors on GDP has been changed. In this case, the following hypotheses have been proposed to account for the impact of each explanatory variable on GDP based on the majority results of previous studies:

H1: Manufacturing has a statistically positive and significant influence on GDP.

H2: Investment has a significant and positive influence on GDP.

H3: Labor force has a significant and positive influence on GDP.

H4: Technology has a positive and influence on GDP.

\section{DATA AND METHODOLOGY}

\subsection{Collection of Data}

The data for twenty-five countries which are classified as the most competitive economies in Europe (World Economic Forum, 2017) for the period 1995-2016 has been collected from the World Bank database. Moreover, the period was selected due to data availability for the chosen countries. As such, the panel data includes 551 country-year observations.

\subsection{Variables and Model}

Due to dispersion of variables means and in order to transfer the data to normal distribution form, the natural logarithm of variables has been used in this study, which shows the growth percentage in every unit of them. Furthermore, Gross Domestic Product (GDP) has been taken as the proxy of an economy size which plays the role of the response variable in the model. Additionally, manufacturing value added is used as an indicator of manufacturing output (Szirmai and Verspagen, 2015), gross fixed capital formation as a proxy for investment (Oburot and Ifere, 2017), employment ratio as proxy for labor force (Swane and Vistrand, 2006), and high-technology exports as a proxy for technology (Fagerberg and Verspagen, 2002; Lall, 2000; Kaderábková and Srholec, 2001; Srholec, 2007). Table 2 denotes an abbreviation of the variables and their final forms which are used in the model specification. The In indicates the natural logarithm of the variable.

Table 2: Summary of the Variables

\begin{tabular}{llc}
\hline Variable Name & Measurement & Abbreviation \\
\hline Economic Growth & Gross Domestic Products (constant 2010 US\$) & InGDP \\
Manufacturing Output & Manufacturing Value Added (constant 2010 US\$) & InMVA \\
Investment & Gross Fixed Capital Formation (\% of GDP) & InCFCF \\
Labor Force & Employment to population ratio ( \% of population) & InEMP \\
Technology & High-Technology Exports (current US\$) & InHTE \\
\hline
\end{tabular}

\subsection{Model Specification}

The theory employed to explore the connection that exists between variables and economic development is combination of Kaldor's first law and neoclassical growth theory. Accordingly, the model specification will be as follows:

$$
\text { InGDP }_{i t}=\beta_{0}+\beta_{1} \text { InMVA }_{i t}+\beta_{2} \text { InGFCF }_{i t}+\beta_{3} \text { InEMP }_{i t}+\beta_{4} \text { InHTE }_{i t}+\varepsilon_{i t}
$$

Where:

InGDP $_{\mathrm{it}}$ : Economic growth determined by the $i^{\text {th }}$ country in period $t$, 
InMVA $A_{\mathrm{it}}$ : Manufacturing output determined by the $i^{\text {th }}$ country in period, InGFCF $_{\text {it }}$ : Capital determined by the $i^{\text {th }}$ country in period, InEMP it: Labor force determined by the $i^{\text {th }}$ country in period, InHTE ${ }_{i t}$ : Technology determined by the $i^{\text {th }}$ country in period, $\varepsilon_{\text {it }}$ : Composite error term.

\section{DATA ANALYSIS AND RESULTS}

In this study, first of all, descriptive statistics has been analyzed. After that, correlation analysis and VIF test have been conducted to uncover the correlations and see whether multicollinearity exists among the variables (Gujarati and Porter, 2009). In addition, the Unit Root Test is used to see if the data is stationary which shows that the mean, variance, and covariance of each variables has not been changed over time (Maddala and $W u$,1999). To estimate the correlation between variables, the Ordinary Least Square (OLS) regression method has been used (Gujarati and Porter, 2009). In order to establish that no connection exists between the individual effect and any variables as dependents, random effects model is employed (Greene, 2008). In addition, to examine the differences in the intercept, the fixed effects model has been conducted (Greene, 2004). Finally, Hausman test has been used to examine the fixed or random effects model which is more suitable and significant for the study framework (Ahn and Low, 1996). Based on results of Hausman test, the fixed effects model is reported in this study. In order to run analysis, the E-views software has been used.

\subsection{Descriptive Analysis}

This analysis introduces an overall glance of variables which contains average, minimum, maximum, and standard deviation of them. The Table 3 contains results for 550 observations were employed in this study for all the variables.

Table 3: Descriptive Statistics

\begin{tabular}{|c|c|c|c|c|c|c|}
\hline & Observation & Mean & Median & Minimum & Maximum & Std. Dev. \\
\hline InGDP & 550 & 26.075 & 26.233 & 21.725 & 28.961 & 1.704 \\
\hline InMVA & 550 & 24.043 & 24.304 & 20.612 & 27.404 & 1.992 \\
\hline InGFCF & 550 & 3.0812 & 3.0833 & 2.4342 & 3.6481 & 0.179 \\
\hline InEMP & 550 & 3.9628 & 3.9815 & 3.5723 & 4.1820 & 0.124 \\
\hline InHTE & 550 & 21.286 & 22.578 & 13.683 & 26.020 & 4.930 \\
\hline
\end{tabular}

\subsection{Correlation Analysis}

Pearson correlation coefficients are calculated to study the connection among these variables as shown in Table 4.

Table 4: Pearson Correlation Matrix

\begin{tabular}{|c|c|c|c|c|c|}
\hline & InGDP & InMVA & InGFCF & InEMP & InHTE \\
\hline InGDP & 1.000 & & & & \\
\hline InMVA & $\begin{array}{l}0.833 \\
(0.000)^{* * *}\end{array}$ & 1.000 & & & \\
\hline InGFCF & $\begin{array}{l}-0.052 \\
(0.216)\end{array}$ & $\begin{array}{l}0.001 \\
(0.979)\end{array}$ & 1.000 & & \\
\hline InEMP & $\begin{array}{l}0.239 \\
(0.000)^{* * *}\end{array}$ & $\begin{array}{l}0.132 \\
(0.001)^{* * *}\end{array}$ & $\begin{array}{l}0.256 \\
(0.000)^{* * *}\end{array}$ & 1.000 & \\
\hline InHTE & $\begin{array}{l}0.669 \\
(0.000)^{* * *}\end{array}$ & $\begin{array}{l}0.549 \\
(0.000) * * *\end{array}$ & $\begin{array}{l}0.233 \\
(0.000)^{* * *}\end{array}$ & $\begin{array}{l}0.431 \\
(0.000)^{* * *}\end{array}$ & 1.000 \\
\hline
\end{tabular}

Note: *Significant at $10 \%,{ }^{* *}$ Significant at $5 \%,{ }^{* *}$ Significant at $1 \%$. 
The result of the correlation matrix demonstrates that the connection among InGDP as dependent variables with three of the independent variables is significant. The correlation between InGDP with InMVA, InEMP, and InHTE is positive and significant. On the other hand, InGFCF has a negative and non-significant association with InGDP. The highest association is between InGDP and InMVA which is at $83 \%$. Also InHTE correlation with InGDP is high at $66 \%$.InEMP has the lowest correlation between independent variables with InGDP which is $23 \%$.

\subsection{Multicollinearity}

According to Kutner, Nachtsheim, Neter, and Li (2005), if the VIF exceed 10 or the tolerance surpasses 1, there is a sign of multicollinearity. The table below depicts the results of these tests (Table 5).

Table 5: Multicollinearity

\begin{tabular}{ccc}
\hline & Tolerance & VIF \\
\hline InMVA & 0.756 & 1.153 \\
InGFCF & 0.965 & 1.036 \\
InEMP & 0.593 & 1.552 \\
InHTE & 0.454 & 1.334 \\
\hline
\end{tabular}

As it is shown in Table 5, VIF for all variables is around one. On the other hand, tolerance for all variables is less than 1 which shows that there is no multicollinearity problem.

\subsection{Unit Root Test}

In this study, various unit root tests developed by Levin, Lin, and Chue (2002) as well as by Im, Pesaran, and Shin (2003) hereafter, IPS, Fisher-PP, and Fisher-ADF have been used. The output of this test is shown in Table 6. Clearly, it has been disclosed that some variables such as InGDP, InMVA, InEMP, and InGFCF are not stationary in their levels, while they are stationary in their first difference level. In addition, InHTE is stationary both in their level and first difference level.

Table 6 : Unit Root Tests

\begin{tabular}{|c|c|c|c|c|c|c|c|c|}
\hline \multirow[b]{2}{*}{ Statistics } & \multicolumn{4}{|c|}{ Level } & \multicolumn{4}{|c|}{ First Differences } \\
\hline & $\begin{array}{l}\text { Levin, Lin } \\
\text { and Chu }\end{array}$ & $\begin{array}{c}\text { Fisher- } \\
\text { ADF }\end{array}$ & Fisher-PP & IPS & $\begin{array}{l}\text { Levin, Lin } \\
\text { and Chu }\end{array}$ & $\begin{array}{c}\text { Fisher- } \\
\text { ADF }\end{array}$ & $\begin{array}{c}\text { Fisher- } \\
\text { PP }\end{array}$ & IPS \\
\hline \multicolumn{9}{|l|}{ InGDP } \\
\hline Statistic & $\begin{array}{l}-6.203 \\
(* * *)\end{array}$ & 61.615 & $\begin{array}{c}133.820 \\
(* * *)\end{array}$ & $\begin{array}{c}-1.479 \\
(*)\end{array}$ & $\begin{array}{l}-9.423 \\
(* * *)\end{array}$ & $\begin{array}{c}138.084 \\
(* * *)\end{array}$ & $\begin{array}{c}155.656 \\
(* * *)\end{array}$ & $\begin{array}{l}-7.008 \\
(* * *)\end{array}$ \\
\hline \multicolumn{9}{|l|}{ InMVA } \\
\hline Statistic & 13.309 & $\begin{array}{c}63.646 \\
(*)\end{array}$ & $\begin{array}{c}355.594 \\
(* * *)\end{array}$ & $\begin{array}{c}-1.536 \\
\left({ }^{*}\right)\end{array}$ & 63.785 & $\begin{array}{c}204.206 \\
(* * *)\end{array}$ & $\begin{array}{c}570.645 \\
(* * *)\end{array}$ & $\begin{array}{c}-10.535 \\
(* * *)\end{array}$ \\
\hline \multicolumn{9}{|l|}{ InGFCF } \\
\hline Statistic & $\begin{array}{c}-2.195 \\
(* *)\end{array}$ & 61.838 & 46.736 & $\begin{array}{c}-1.704 \\
(* *)\end{array}$ & $\begin{array}{l}-8.611 \\
(* * *)\end{array}$ & $\begin{array}{c}171.503 \\
(* * *)\end{array}$ & $\begin{array}{c}202.711 \\
(* * *)\end{array}$ & $\begin{array}{l}-8.605 \\
(* * *)\end{array}$ \\
\hline \multicolumn{9}{|l|}{ InEMP } \\
\hline Statistic & $\begin{array}{l}-3.708 \\
(* * *)\end{array}$ & $\begin{array}{c}75.966 \\
(* *)\end{array}$ & 55.023 & -2.698 & $\begin{array}{c}-4.660 \\
(* * *)\end{array}$ & $\begin{array}{c}111.335 \\
(* * *)\end{array}$ & $\begin{array}{c}170.407 \\
(* * *)\end{array}$ & $\begin{array}{c}-5.409 \\
(* * *)\end{array}$ \\
\hline InHTE & & & & & & & & \\
\hline Statistic & $\begin{array}{l}-5.735 \\
(* * *)\end{array}$ & $\begin{array}{c}84.416 \\
(* * *)\end{array}$ & $\begin{array}{c}79.960 \\
(* * *)\end{array}$ & $\begin{array}{l}-2.626 \\
(* * *)\end{array}$ & $\begin{array}{c}-7.744 \\
(* * *)\end{array}$ & $\begin{array}{c}149.231 \\
(* * *)\end{array}$ & $\begin{array}{c}282.719 \\
(* * *)\end{array}$ & $\begin{array}{l}-7.631 \\
(* * *)\end{array}$ \\
\hline
\end{tabular}

Note: *Significant at $10 \%,{ }^{*}$ Significant at $5 \%, * * *$ Significant at $1 \%$. 


\subsection{OLS Regression}

Table 7 depicts the results of OLS regression model to identify the association between dependent and independent variables.

Table 7: OLS Regression

\begin{tabular}{clll}
\hline Variable & Coefficient & Std. Error & t-Statistic \\
\hline Constant & 12.81796 & 1.571452 & $9.6424554(* * *)$ \\
InMVA & 0.454699 & 0.034588 & $10.657438(* *)$ \\
InGFCF & -1.868048 & 0.202577 & $-7.625738(* * *)$ \\
InEMP & 0.537471 & 0.475515 & $3.1525414(* *)$ \\
InHTE & 0.162319 & 0.008774 & $12.882541(* * *)$ \\
\hline R2: 0.55711 & & F-statistic: 420.0425 \\
\hline Adjusted R2: 0.555482 & & Prob(F-statistic): $0.000000(* * *)$ \\
\hline
\end{tabular}

Note: *Significant at $10 \%, * *$ Significant at $5 \%, * * *$ Significant at $1 \%$.

According to the results, all the variables are strongly significant at the $1 \%$ and $5 \%$ confidence level. While all variable effect the economic growth in a positive direction, the gross fixed capital formation (GFCF) influences the economic growth in opposite direction among them.

\subsection{Hausman Test}

The result of this test is presented in Table 8 . Indeed in this test, the null hypothesis is such that the fixed effects model depicts

\section{Table 8: The Hausman Test}

\begin{tabular}{lccc}
\hline Summary of Test & Chi-Sq. Statistic & d.f. & Prob. \\
\hline Cross-section random & 419.338384 & 4 & 0.0000 \\
\hline
\end{tabular}

\subsection{Fixed Effects Model}

As a result, the Hausman test denotes the validity of fixed effect model. The table below (Table 9) displays the outcomes of fixed effect models from the dependent variable, InGDP, and independent variables. The overall results are similar to the OLS's model.

Table 9: Fixed Effects Model

\begin{tabular}{cccc}
\hline Variable & Coefficient & Std. Error & t-Statistic \\
\hline Constant & 18.64542 & 0.452144 & $38.52022\left({ }^{* * *}\right)$ \\
InMVA & 0.061542 & 0.008141 & $6.935021\left(^{* *}\right)$ \\
InGFCF & -0.132541 & 0.082411 & $4.19007\left(^{* *}\right)$ \\
InEMP & 1.786124 & 0.263328 & $7.22146\left({ }^{* * *}\right)$ \\
InHTE & 0.028712 & 0.003414 & $8.02504(* * *)$ \\
\hline R2: 0.471215 & \multicolumn{3}{c}{ F-statistic: 2467.287} \\
\hline Adjusted R2: 0.572426 & Prob(F-statistic): $0.000000(* * *)$ \\
\hline
\end{tabular}

Note: *Significant at $10 \%, * *$ Significant at $5 \%, * * *$ Significant at $1 \%$. 
In this specification, a significant positive influence is exerted on the GDP by the manufacturing value added (MVA) at the $5 \%$ significance level. For GDP, the gross fixed capital formation has a negative influence at the $5 \%$ significance level based on the result. Employment ratio (EMP) has a positive significant influence on GDP but at the $1 \%$ significance level. Likewise, high tech export (HTE) has a positive significant impact on GDP at $1 \%$ level of significance. Based on the fixed effects estimation model, the resulting equation is as follows:

$$
\operatorname{InGDP}_{i t}=18.64+0.06 \operatorname{InMVA}_{\text {it }}-0.13 \operatorname{InGFCF}_{\text {it }}+1.78 \operatorname{InEMP}_{\text {it }}+0.02 \operatorname{InHTE}_{\text {it }}+\varepsilon_{i t}
$$

Based on the output in the preceding table, the effects of manufacturing value added (MVA), employment ratio (EMP), and high-tech export (HTE) are positive, while the impact of gross fixed capital formation, is negative. Based on this analysis, the change in the rate of economic growth is about $0.06 \%$ by manufacturing value added in terms of every $1 \%$ rise in the independent variables. Equally, this rate is $1.78 \%$ by employment ratio, $0.02 \%$ by high-tech export and $-0.13 \%$ by gross fixed capital formation. Meanwhile, the $p$-value for the overall test in the total model denotes that it is generally significant.

\section{FINDINGS AND DISCUSSIONS}

\subsection{Evaluations of Findings}

According to OLS regression and fixed effects models, MVA is positively associated with GDP at the 5\% significant level. Regarding the two regression models, the employment ratio has a significant positive association with GDP with the 1\% significant level in OLS and fixed effects models. In addition, based on the regression models HTE is correspondingly positively associated with GDP with the $1 \%$ significant level. Based on this analysis, the results support Hypotheses 1,3 , and 4 . The entire Hypotheses' results are illustrated in Table 10.

Table 10: Hypotheses Results

\begin{tabular}{ll}
\hline Hypotheses & Results \\
\hline H1: Manufacturing has a statistically positive and significant influence on GDP. & Supported \\
H2: Investment has a significant and positive influence on GDP. & Rejected \\
H3: Labor force has a significant and positive influence on GDP. & Supported \\
H4: Technology has a positive and influence on GDP. & Supported \\
\hline
\end{tabular}

According to the empirical results, the relationship between manufacturing output and economic growth is significantly positive. It is applicable for policymakers, such that the manufacturing output attributes to an upside trend in economic growth, due to the fact that this nexus is not almost one to one; that is, in terms of a $6 \%$ percentage rise in the manufacturing value added rate, the rate of increase in economic growth is about $1 \%$. Therefore, they will be able to raise the level of economic development and enhancing European countries' competitiveness by increasing the manufacturing output.

Unfortunately, there is a significantly negative effect on economic growth by investment which shown by gross fixed capital formation in the model. After the financial crisis 2009 most of European countries reduced their domestic investment level (Ksantini and Boujelbène, 2014) and the European Commission debated over more investment in order to accelerate the recovery process of economic growth (European Commission report, 2009). The effects of those funds and increase in financial costs had a negative effect on economic growth (Andrade and Duarte, 2017). This negative effect is known as Dutch Disease which implies the causal relationship between the development of a specific sector and a decline in other sectors .Actually, the expansion of a sector (e.g. natural resources or truism) can play an important role in enhancing total foreign exchange earning which causes depreciation of domestic currency. Consequently, other sectors become less competitive in international market 
and the export level of country decrease which can affect the GDP negatively .Furthermore the conducted research indicates that for countries that joined the European Union in the last years, the intensified investment process triggered an increased demand for working capital, due to the undercapitalization of companies during the transition period. At the same time, the greater demand for working capital could also be a result of a lower efficiency in using the production factors in comparison with West European countries (PAVELESCU, 2008). It clearly shows that policy makers should focus on investment policies to increase physical assets for recovering economic development in future.

Moreover, the other two explanatory variables, labor force, and technology, denotes a significantly positive growth effect on the economy. It shows that the government should decrease the unemployment rate by creating new job opportunities by several ways such as cutting tax rate, reducing prices, increasing employee salaries, and wages, hiring workers directly, etc. in order to accelerate the economic growth.

In addition to technology, effective investment and stimulus policies in the technology and innovation sector will help the countries to enhance the rate of economic growth. Of late, an emphasis has been placed on the role of a robust industry and real economy as a drive for employment and economic development by the European Commission.

\subsection{Research Implications}

Based on result of this study we know that industrialization acted as an engine of growth in Europe's competitive economies during the past decade. According to future European Commission objectives, the policies should now focus on the modalities by which industrialization takes place and, in particular, on the drivers of this process. It is recommended that policy makers should invest in those policies that can enhance the growth of the manufacturing sector by increases of manufacturing productivity and increases in the manufacturing employment share to create new job opportunities in this sector in order to have sustainable, healthy and competitive economic development in future. In other words, structural change towards the manufacturing sector and increased manufacturing productivity are the key policy variables to be prioritized by policymakers (Cantore, Clara, Lavopa, and Soare, 2017).

Based on results and positive role of technology growth on economic development, the European Commission should design the policies in order to open the doors for inventors and entrepreneurs by legislating incentive laws for registering new ideas, localize the inventions, monitoring the innovation policies and legislating new policies (Firth and Mellor, 1999; Borrus and Stowsky, 1997).

With regards to the negative effect of investment on economic growth in third biggest economic region in the world, it implies that not only the amount of fixed investments plays a significant role in countries' development process but also the structure of investment across economic activities matters as it affects the rates of economic growth (Tvaronavičius and Tvaronavičiene, 2008). The European Commission structural changes has focused more on investing in small markets (economic of scale) and according to this point that in the European economic region larger markets seem to attract capital of all types of sectors with a more even relative allocation (Stirböck, 2002), it might be more effective for European Union to allocate more expenditure to invest in large markets as well. Furthermore, main role in compounding parts of fixed investment in Europe region is being attributed to equipment and construction capital formation activities (Tvaronavičius and Tvaronavičiene, 2008). Thus, the policy makers should allocate more consideration to other sectors such as manufacturing in order to create a positive effect of investment on economic growth.

\subsection{Research Limitations and Future Works}

The most significant restriction of this research is the lack of statistical data for the variables in selected countries before 1995. Another remarkable limitation is that this study used only OLS regression which precludes the author from running a time series regression corresponding to each country so as to compare the connections that exist between the variables among crosssections. Probably, future studies should focus on the other regressions models such as GMM (Generalized Method of Moments) dynamic model to make a comparison between the variables among cross-sections. Additionally, another limitation is that this study employed high-tech export as the proxy for technology. Again, future studies should focus on different types of 
technology proxies as well as different activities such as expenditure on Research and Developed (RandD) as a factor that might influence GDP.

\section{CONCLUSION}

The study's goal is to probe the dynamics influencing economic growth in 25 of most competitive economies in Europe. The accelerating process of deindustrialization, due to the economic and financial crunch of 2008-2009, underscored the susceptibility of the European industry, particularly the manufacturing sector. Therefore, it's an imperative need to find other means of economic development (Dhéret and Morosi, 2014). A World Economic Forum Report emphasized that manufacturing is considered essential to the wealth of nations as more $70 \%$ of 128 nations' income (World Economic Forum, 2012). Based on Eurostat (2017), manufacturing was the second biggest economic sector (within Europe's non-financial business economy) of the NACE sections in Europe as per its biggest contribution to non-financial business economy value added and job creation. This topic has not been considered among the most competitive economies in Europe so far. However, managing economic growth and its determinants, specifically the manufacturing sector, is fundamentally important in any country. Therefore, this paper is an interesting area for research.

Twenty-five top European economies in the global competitive index have been chosen to specify the factors which affect the economic growth during 1995 - 2016. Furthermore, Gross Domestic Product (GDP) has been taken as the dependent variable and MAV, GFCF, EMP, and HTE are the independent variables. Thus, different regression models, such as OLS, fixed effects model, and random effects model are run to achieve study's goal. Additionally, the Hausman tests have been employed in determining the model that is most appropriate between the random effects model and the fixed effects model. The corresponding results specified that the random effects model is outperformed by the fixed effects model. As a result, it is explored that the explanatory variables have significant effects on economic growth.

The result of this study revealed that the economic growth has a significantly positive association with manufacturing, labor force, and technology. The unexpected interesting result is that the association between economic growth and investment is significantly negative.

\section{REFERENCES}

Ahn, S. C., and Low, S. (1996). A reformulation of the Hausman test for regression models with pooled cross-section-time-series data. Journal of Econometrics, 71(1-2), 309-319.

Arestis, P., Sawyer, M., and Palma, G. (2005). Markets, Unemployment and Economic Policy: Essays in Honour of Geoff Harcourt, Volume Two. Routledge.

Banjoko, S. A., Iwuji, I. I., and Bagshaw, K. (2012). The performance of the Nigerian manufacturing sector: A 52-year analysis of growth and retrogression (1960-2012). Journal of Asian Business Strategy, 2(8), 177-191.

Blomstrom, M., Lipsey, R. E., and Zejan, M. (1993). Is fixed investment the key to economic growth? (No. w4436). National Bureau of Economic Research.

Boltho, A., and Glyn, A. (1995). Can macroeconomic policies raise employment. Int'I Lab. Rev., 134, 451.

Borrus, M., and Stowsky, J. (1997). Technology policy and economic growth.

Bujari, A. A., and Martínez, F. V. (2016). Technological Innovation and Economic Growth in Latin America. Revista Mexicana de Economía y Finanzas (REMEF): nueva época, 11(2), 77-89.

Cantore, N., Clara, M., Lavopa, A., and Soare, C. (2017). Manufacturing as an engine of growth: Which is the best fuel?. Structural Change and Economic Dynamics, 42, 56-66.

Chakravarty, S., and Mitra, A. (2009). Is industry still the engine of growth? An econometric study of the organized sector employment in India. Journal of Policy Modeling, 31(1), 22-35.

DOI: 10.17261/Pressacademia.2019.1044 
De Long, J. B., and Summers, L. H. (1991). Equipment investment and economic growth. The Quarterly Journal of Economics, 106(2), 445-502. Dhéret, C., and Morosi, M. (2014). Towards a New Industrial Policy for Europe. EPC Issue Paper No. 78, November 2014.

Dragutinović, D., Filipović, M., and Cvetanović, S. (2005). The theory of economic growth and development. Ekonomski fakultet Beograd.

Dritsakis, N., Varelas, E., and Adamopoulos, A. (2006). The main determinants of economic growth: An empirical investigation with Granger causality analysis for Greece. European Research Studies Journal, 9(3-4), 47-58.

Evangelista, E., Pianta, M., and Perani, G. (1996). The dynamics of innovation and employment: an international comparison. STI review, 18, 6793.

Fagerberg, J., and Verspagen, B. (1999). Modern Capitalism in the 1970s and 1980s., table 9.1, lin M. Setterfield ed., Growth, Employment and Inflation.

Fagerberg, J., and Verspagen, B. (2002). Technology-gaps, innovation-diffusion and transformation: an evolutionary interpretation. Research policy, 31(8-9), 1291-1304.

Falk, M. (2009). High-tech exports and economic growth in industrialized countries. Applied Economics Letters, 16(10), 1025-1028.

Firth, L., and Mellor, D. (1999). The impact of regulation on innovation. European Journal of Law and economics, 8(3), 199-205.

Gani, A. (2009). Technological achievement, high technology exports and growth. Journal of Comparative International Management, 12(2).

Greene, W. (2004). The behaviour of the maximum likelihood estimator of limited dependent variable models in the presence of fixed effects. The Econometrics Journal, 7(1), 98-119.

Greene, W. H. (2008). The econometric approach to efficiency analysis. The measurement of productive efficiency and productivity growth, 1(1), 92-250.

Gujarati, D. N., and Porter, D. (2009). Basic Econometrics. McGraw-Hill/Irwin.

Herman, E. (2016). The importance of the manufacturing sector in the Romanian economy. Procedia Technology, 22, 976-983.

Ibrahim, W., and Okunade, A. S. (2015). Analysis of Foreign and Domestic Investment on Economic Growth in Nigeria (1980-2013). Artha-Journal of Social Sciences, 14(4), 41-58.

Im, K. S., Pesaran, M. H., and Shin, Y. (2003). Testing for unit roots in heterogeneous panels. Journal of econometrics, 115(1), 53-74.

Kaderábková, A., and Srholec, M. (2001). Structural changes in transition economies. Prague Economic Papers, 6(4), 335-351.

Kaldor, N. (1966). Marginal productivity and the macro-economic theories of distribution: comment on Samuelson and Modigliani. The Review of Economic Studies, 33(4), 309-319.

Kathuria, V., and Natarajan, R. R. (2013). Is manufacturing an engine of growth in India in the post-nineties?. Journal of South Asian Development, 8(3), 385-408.

Kathuria, V., Raj, R. S., and Sen, K. (2013). Productivity measurement in Indian manufacturing: A comparison of alternative methods. Journal of Quantitative Economics, 11(1/2), 148-179.

Kolmakov, V. V., Polyakova, A. G., and Shalaev, V. S. (2015). An analysis of the impact of venture capital investment on economic growth and innovation: evidence from the USA and Russia. Economic Annals, 60(207), 7-37.

Kutner, M. H., Nachtsheim, C. J., Neter, J., and Li, W. (2005). Applied linear statistical models

Lall, S. (2000). The Technological structure and performance of developing country manufactured exports, 1985-98. Oxford development studies, 28(3), 337-369.

Levin, A., Lin, C. F., and Chu, C. S. J. (2002). Unit root tests in panel data: asymptotic and finite-sample properties. Journal of econometrics, 108(1), 1-24.

Libanio, G., and Moro, S. (2006, December). Manufacturing industry and economic growth in Latin America: A Kaldorian approach. In Second Annual Conference for Development and Change. 
Maddala, G. S., and Wu, S. (1999). A comparative study of unit root tests with panel data and a new simple test. Oxford Bulletin of Economics and statistics, 61(S1), 631-652.

Nasreen, S., Anwar, S., and Waqar, M. Q. (2015). Institutions, investment and economic growth: A cross-country and panel data study. The Singapore Economic Review, 60(04), 1550061.

Naudé, W., Szirmai, A., and Haraguchi, N. (2016). Structural transformation in Brazil, Russia, India, China and South Africa (BRICS) (No. 016). United Nations University-Maastricht Economic and Social Research Institute on Innovation and Technology (MERIT).

OYATI, E. (2010). The Relevance, Prospects and the Challenges of the Manufacturing Sector in Nigeria. Department of Civil Technology, Auchi Polytechnic.

PAVELESCU, F. M. (2008). Gross capital formation and economic growth during early 2000's in EU-member and candidates states. Romania, 11(12.17), 0-48.

Rowthorn, R., and Ramaswamy, R. (1997). Growth, trade and deindustrialization. In IMF Working Paper, WP/97/42. IMF Washington DC.

Seyfried, W. (2011). Examining the relationshi p between employment and economic growth in the ten largest states. Southwestern Economic Review, 32, 13-24.

Solow, R. M. (1956). A contribution to the theory of economic growth. The quarterly journal of economics, 70(1), 65-94.

Srholec, M. (2007). High-tech exports from developing countries: A symptom of technology spurts or statistical illusion?. Review of World Economics, 143(2), 227-255.

Stirböck, C. (2002). Relative Specialisation of EU Regions: An Econometric Analysis of Sectoral Gross Fixed Capital Formation.

Su, D., and Yao, Y. (2017). Manufacturing as the key engine of economic growth for middle-income economies. Journal of the Asia Pacific Economy, 22(1), 47-70.

Swane, A., and Vistrand, H. (2006). Jobless growth in Sweden? A descriptive study. Unpublished Master's Thesis, Stockholm School of Economics, Stockholm.

Szirmai, A. (2012). Industrialisation as an engine of growth in developing countries, 1950-2005. Structural change and economic dynamics, 23(4), 406-420.

Szirmai, A., and Verspagen, B. (2015). Manufacturing and economic growth in developing countries, 1950-2005. Structural Change and Economic Dynamics, 34, 46-59.

Tvaronavičius, V., and Tvaronavičiene, M. (2008). Role of fixed investments in economic growth of country: Lithuania in European context. Journal of Business Economics and Management, 9(1), 57-64. 